\title{
Relationship between components of inclusion and hydrocarbon accumulation in the Yunlong Depression, Chuxiong Basin
}

\author{
Xie Qingbin *, Guan Shourui, Jiao Daqing and Geng Huiju \\ School of Resources and Information Technology, China University of Petroleum, Beijing 102249, China
}

\begin{abstract}
The Yunlong Depression, Chuxiong Basin, Yunnan Province, southwest China is one of the least explored areas in China. A RAMANOR-U1000 laser Raman probe was used to investigate the gas phase and liquid phase components in 28 inclusions from outcrop and core in the Yunlong Depression. An investigation into hydrocarbon prospect and accumulation characteristics in the study area was performed by studying inclusion components. Oil and gas are the richest in the Devonian according to the organic inclusion content, which supports the prior research findings with conventional methods. Multitime accumulation of oil and gas in the study area was also recognized through analysis of inclusion components. This study could provide a reference for the exploration of oil and gas in this area.
\end{abstract}

Key words: Inclusion component, hydrocarbon accumulation, oil and gas resources, Yunlong Depression

\section{Introduction}

The Yunlong Depression is situated in the east shallow depression area of the Chuxiong Basin in the Yangtze Plate, with the west edge of the Pudu River Fault as its east boundary and the Yimen Fault in the west (Fig. 1). Its basement is composed of shallow metamorphic rock system such as slate, marble, phyllite and dolomite of the Kunyang Group, and the sedimentary seal is marine carbonates, sandstones and mudstones of the Sinian, Cambrian, Ordovician, Devonian and Permian at its bottom and fluvial and lacustrine sandstones and mudstones of the Shezi Group of upper Triassic - Eogene on its top. The main exploration targets are the Shezi Group of the upper Triassic, middle and lower Devonian and Cambrian. At present, the degree of exploration is relatively low and only one well has been drilled.

Organic inclusions, provide the only sample of the original oil and gas, and could provide direct information of initial accumulation and reflect physico-chemical conditions of accumulation. In recent years, with the introduction and development of sophisticated testing technology, inclusion studies are becoming more and more important to petroleum geologists (Zheng et al, 1998). Many scholars explored the thermal evolution history of basin (Levine et al, 1991; Shelton et al, 1992; Braithwaite, 1993; Pan et al, 2007), oil and gas pool evolution history of migration and accumulation (Mei et al, 1994; Zhu and Zeng, 2008; He and Du, 1996; Mai and Wang, 1991), prediction and evaluation of reservoirs (Itansen and Madsen, 1995; Sasada, 1995; Shi and Li, 1991; Zhang and Zhang, 1994; Tan et al, 1994; Feng, 2006; Liu et al, 2007;

*Corresponding author. email: xieqingbin@cup.edu.cn

Received April 18, 2008

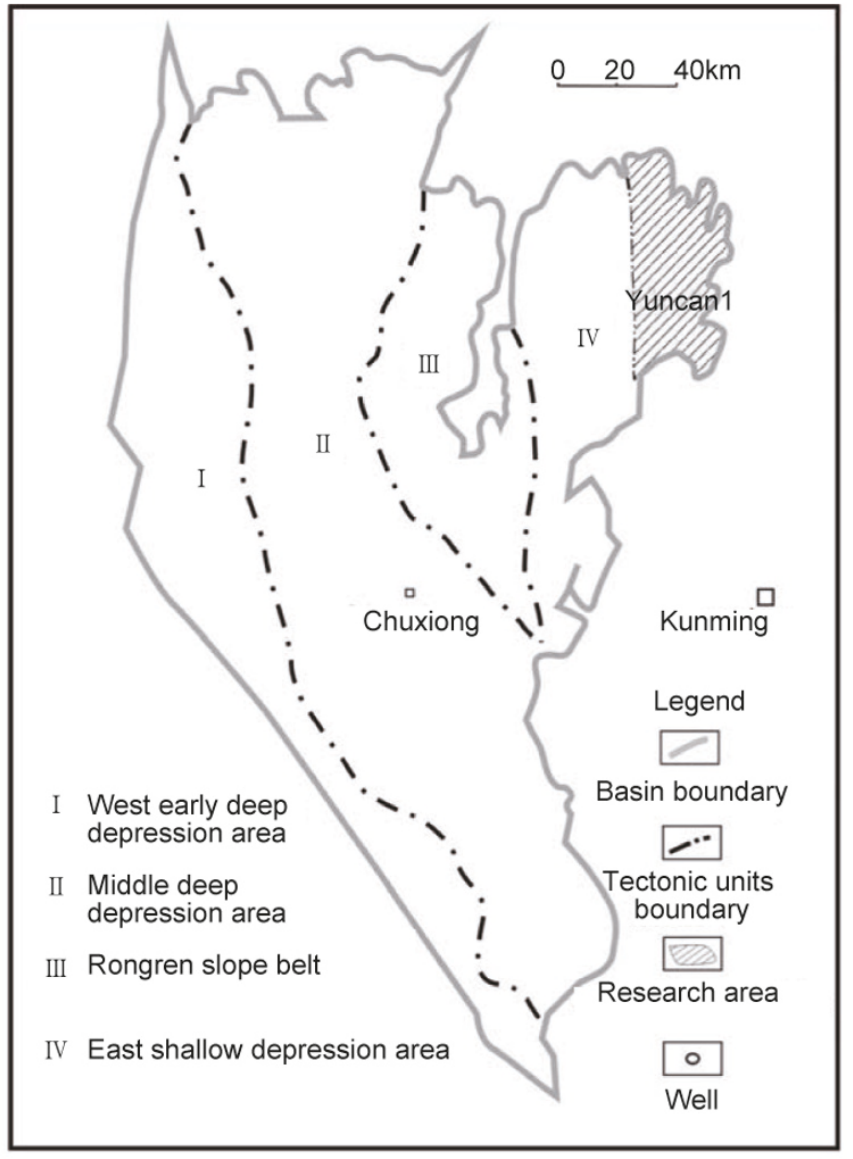

Fig. 1 Map showing the tectonic units and the study area in the Chuxiong Basin

Wang et al, 2006), and achieved useful results. In this paper, an investigation of hydrocarbon prospect and accumulation characteristics of the study area is presented from analysis of 
the inclusion components of outcrop and core samples.

\section{Method of inclusion components analysis}

Outcrop and core samples of the reservoir beds in the Yunlong Depression were used in the method. First of all, we studied microscopic characteristics in detail to choose the samples with inclusions, and then the inclusion components were tested in the Xi' an Institute of Geology and Minerals Resources. The testing used a RAMANOR-U1000 laser Raman probe manufactured by the French Jobin-Yvon Instrument Company. The experimental conditions were as follows: $\mathrm{Ar}^{+}$laser wavelength $541.5 \mathrm{~nm}$, laser capacity $300 \mathrm{mw}$, double-monochromator slit $450 \mu \mathrm{m}$, relative dispersion $9.2 \mathrm{~cm}-1 / \mathrm{mm}$, photoelectric multiplier tube high pressure $1530 \mathrm{~V}$, temperature $23^{\circ} \mathrm{C}$, moisture $65 \%$, optical spectrum range $11000-32000 \mathrm{~cm}^{-1}$, accuracy $+/-1 \mathrm{~cm}^{-1}$, resolution $0.15 \mathrm{~cm}^{-1}$ (single channel) $-0.80 \mathrm{~cm}^{-1}$ (multi-channel), and repeatability $+/-0.1 \mathrm{~cm}^{-1}$ (Xu et al, 1996). The laser Raman spectra are shown in Fig. 2. Qualitative analysis depends on the position of wave crest, and quantitative analysis depends on the peak height.

\section{Characteristics of inclusion components}

The analysis results of the inclusion components are shown in Table 1 and Table 2. In the organic inclusions, the characteristics of the gas phase are: 1) The gas phases have a high inorganic content and a low organic content. The inorganic components of the samples account for more than $50 \%$, between $56 \%$ and $96.2 \%$, except for No.5 and No. 28 samples. 2) In the inorganic components, the content of $\mathrm{CO}_{2}$ is high apart from samples 4,5 and 28 which do not contain $\mathrm{CO}_{2}$. The content of $\mathrm{CO}_{2}$ in the other samples is above $20 \%$, and is higher than $50 \%$ in nearly half of the samples. In No.22 sample it is $91.3 \%$. The next is $\mathrm{H}_{2} \mathrm{~S}$ and in most of the samples the content of $\mathrm{H}_{2} \mathrm{~S}$ is greater than $10 \%$. Other inorganic components only exist in a few samples. 3) In the organic components, $\mathrm{CH}_{4}$ exists in most of the samples, but the total content is relatively low, which is less than $20 \%$ in
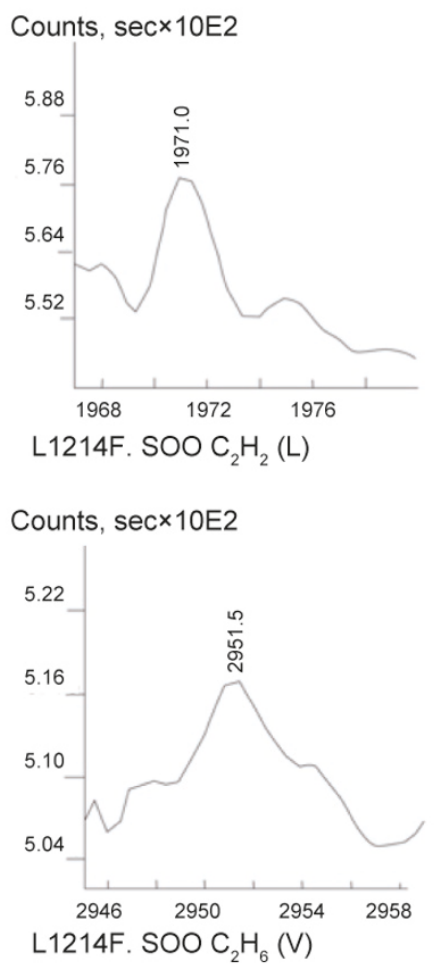

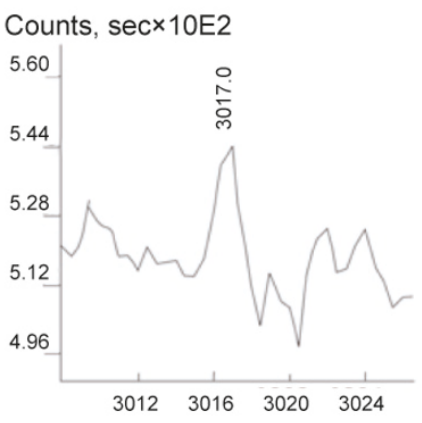

L1214E. SOO C ${ }_{2} \mathrm{H}_{4}(\mathrm{~L})$

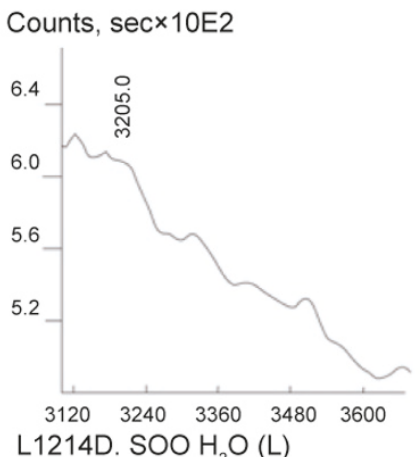

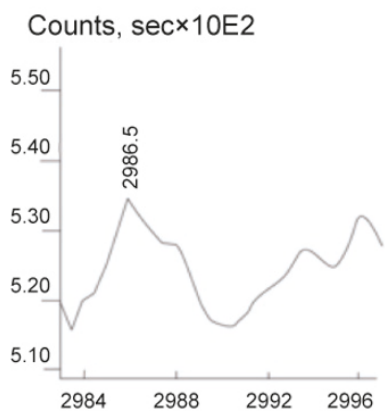

L1214G. SOO CL

Counts, sec $\times 10 E 2$

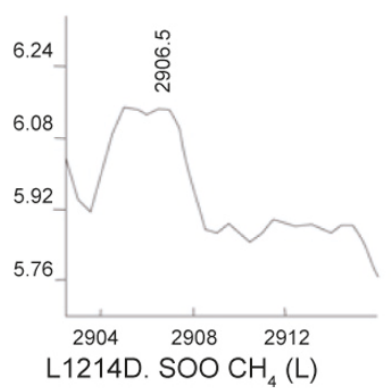

Fig. 2 Laser Raman spectrum (Beiyin Mountain, Triassic)

general. However, the content of $\mathrm{CH}_{4}$ forms a major part of the organic components, that is to say, $\mathrm{C}_{1} / \mathrm{C}_{1-6}$ is high. $\mathrm{C}_{1} / \mathrm{C}_{1-6}$ in most of the samples is above 0.3 , and that in five samples exceeds 1 , which is contrary to the analysis results of the reservoir beds in the Tertiary System in the East China Sea Depression (Jiang et al, 2001).

The characteristics of the liquid phase in organic inclusions are: 1) Compared with the gas phase, the content of organic components is much lower, and the content of inorganic components is much higher. For example, in sample No.15 the content of organic components is $52.3 \%$ and in the other samples the content is less than $50 \%$.
Furthermore, in most of the samples the content of organic components is less than $20 \%$, and there are even completely inorganic components such as sample No.2. 2) The inorganic components are mainly $\mathrm{H}_{2} \mathrm{O}$ and $\mathrm{CO}_{2}$, in which the content of $\mathrm{H}_{2} \mathrm{O}$ is high. The $\mathrm{H}_{2} \mathrm{O}$ content in ten samples is above $80 \%$. $\mathrm{CO}_{2}$ exists in nearly all the samples except Nos.7 and 11. Commonly, the content is between $5.1 \%$ and $79.3 \%$, but it varies greatly among samples. 3) For organic components, half of the samples contain $\mathrm{CH}_{4}$ and the total amount of organic components is low, and the content of $\mathrm{CH}_{4}$ is less than $25 \%$ in all samples. However, its proportion in the whole organic components is still high. $\mathrm{C}_{2} \mathrm{H}_{2}$ is the second in the 
samples with a low content which is less than $10 \%$.

\section{Types of organic inclusion and types of potential reservoir}

The characteristics and evolution of hydrocarbons could be reflected by the types and characteristics of organic inclusions (Zhang and Chen, 1993). The types and characteristics of organic inclusions are obviously different for oil and gas reservoirs. Generally speaking, commercial oil reservoirs show mostly pure liquid inclusions or liquid hydrocarbon inclusions with a small proportion of gaseous hydrocarbon inclusions, where the volume of liquid hydrocarbon inclusions accounts for more than $60 \%$. However, commercial gas reservoirs show mostly pure gaseous inclusions or gas rich inclusions. In non-hydrocarbon layers only a few liquid hydrocarbon or gaseous hydrocarbon inclusions exist, and sometimes there are no organic inclusions.

Table 1 Analysis data and ratios of the laser Raman spectrum experiment on liquid phase of fluid inclusions in the Yunlong Depression

\begin{tabular}{|c|c|c|c|c|c|c|c|c|c|c|c|c|c|c|c|c|c|c|}
\hline \multirow{2}{*}{$\begin{array}{l}\text { Sample } \\
\text { number }\end{array}$} & \multirow{2}{*}{ Layer } & \multicolumn{9}{|c|}{ Organic components, $\%$} & \multicolumn{5}{|c|}{ Inorganic components, $\%$} & \multicolumn{3}{|c|}{ Ratio } \\
\hline & & $\mathrm{CH}_{4}$ & $\mathrm{C}_{2} \mathrm{H}_{6}$ & $\mathrm{C}_{3} \mathrm{H}_{8}$ & $\mathrm{C}_{2} \mathrm{H}_{4}$ & $\mathrm{C}_{4} \mathrm{H}_{6}$ & $\mathrm{C}_{3} \mathrm{H}_{6}$ & $\mathrm{C}_{6} \mathrm{H}_{6}$ & $\mathrm{C}_{2} \mathrm{H}_{2}$ & Organic total & $\mathrm{CO}_{2}$ & $\mathrm{H}_{2} \mathrm{~S}$ & $\mathrm{H}_{2} \mathrm{O}$ & $\mathrm{SO}_{2}$ & Inorganic total & A & B & $\mathrm{C}$ \\
\hline 1 & $\mathrm{~K}$ & 16.2 & 4.5 & & 19.3 & & & & 5.8 & 45.8 & 54.2 & & & & 54.2 & 0.23 & 0.45 & 0.35 \\
\hline 2 & $\mathrm{~K}$ & & & & & & & & & 0 & 13.5 & & 79.2 & 7.3 & 100 & 0 & 0 & 0 \\
\hline 3 & $\mathrm{~J}$ & & 14.1 & 12.3 & & & & & & 26.4 & 52.2 & 21.4 & & & 73.6 & 0 & 1 & 0 \\
\hline 4 & $\mathrm{~J}$ & & & & & & 14.1 & & 2.9 & 17 & 18.8 & 9.5 & 54.7 & & 83 & 0 & 0 & 0 \\
\hline 5 & $\mathrm{~J}$ & 13.5 & & & & & 10.9 & 8.5 & 9.5 & 42.4 & 48.8 & 8.8 & & & 57.6 & 0.22 & 0.32 & 0.32 \\
\hline 6 & $\mathrm{~T}$ & 11.3 & & & & 3.6 & & 5.8 & & 20.7 & \begin{tabular}{|l|}
79.3 \\
\end{tabular} & & & & 79.3 & 0.12 & 0.55 & 0.55 \\
\hline 7 & $\mathrm{~T}$ & 3.3 & & & 5.1 & & & & 2.1 & 10.5 & & & 89.5 & & 89.5 & 0.04 & 0.31 & 0.31 \\
\hline 8 & $\mathrm{~T}$ & & & 2.2 & & & & & & 2.2 & 6.5 & 4.6 & 86.7 & & 97.8 & 0 & 1 & 0 \\
\hline 9 & $\mathrm{~T}$ & & 1.2 & & & & & 1.5 & & 2.7 & 17.7 & 2.5 & 77.1 & & 97.3 & 0 & 0.44 & 0 \\
\hline 10 & $\mathrm{~T}$ & & & 1.6 & & & & & & 1.6 & 7 & & 87.7 & 3.7 & 98.4 & 0 & 1 & 0 \\
\hline 11 & $\mathrm{~T}$ & 3.6 & & & & & & & 3 & 6.6 & & 5.1 & 88.3 & & 93.4 & 0.04 & 0.55 & 0.55 \\
\hline 12 & $\mathrm{D}$ & 12.2 & & & 12.7 & & & & 9.2 & 34.1 & 44 & & & 21.9 & 65.9 & 0.22 & 0.36 & 0.36 \\
\hline 13 & $\mathrm{D}$ & 2.7 & & 1.6 & & & & & 1.5 & 5.8 & 5.1 & & 86.5 & 2.8 & 94.4 & 0.03 & 0.74 & 0.47 \\
\hline 14 & $\mathrm{D}$ & 23.2 & 6.1 & & 10.9 & & & & 7.8 & 48 & 52 & & & & 52 & 0.31 & 0.61 & 0.48 \\
\hline 15 & $\mathrm{O}$ & 16.3 & 7.5 & & 10 & 18.5 & & 7.9 & & 52.3 & 47.7 & & & & 47.7 & 0.26 & 0.46 & 0.31 \\
\hline 16 & $\mathrm{O}$ & & & 1.3 & & & & 10.1 & 2.2 & 3.5 & 12.3 & & 84.2 & & 96.5 & 0 & 0.37 & 0 \\
\hline 17 & $\mathrm{O}$ & 16.4 & 4.4 & & & & & & & 28.7 & 52.8 & & & 18.5 & 71.3 & 0.24 & 0.72 & 0.57 \\
\hline 18 & $\mathrm{O}$ & & & & 16.2 & & & & & 26.3 & 61.5 & 12.2 & & & 73.7 & 0 & 0 & 0 \\
\hline 19 & $\mathrm{O}$ & 3.4 & & & & & & 5.5 & & 3.4 & 7.9 & & 85.7 & 3 & 96.6 & 0.04 & 1 & 1 \\
\hline 20 & $\mathrm{O}$ & & & & 2.1 & & & & 1.3 & 3.4 & 15.7 & & 79.2 & 1.7 & 96.6 & 0 & 0 & 0 \\
\hline 21 & $\in$ & 20.2 & & & & & & & & 25.7 & 64.2 & 10.1 & & & 74.3 & 0.24 & 0.79 & 0.79 \\
\hline 22 & $\in$ & & & & & 3.1 & & & 3.4 & 6.5 & 5.7 & 3.7 & 84.1 & & 93.5 & 0 & 0 & 0 \\
\hline 23 & $\in$ & 2.2 & & & 1.5 & & & & & 3.7 & 14.8 & & 81.5 & & 96.3 & 0.02 & 0.59 & 0.59 \\
\hline 24 & $\in$ & & & & & 2.9 & 4.1 & & & 7 & 13.6 & & 79.4 & & 93 & 0 & 0 & 0 \\
\hline 25 & $\in$ & & & 2.3 & & & 4.9 & 1.6 & & 8.8 & 10.2 & & 81 & & 91.2 & 0 & 0.26 & 0 \\
\hline
\end{tabular}


Table 2 Analysis data and ratios of the laser Raman spectrum experiment on gas phase of fluid inclusions in the Yunlong Depression

\begin{tabular}{|c|c|c|c|c|c|c|c|c|c|c|c|c|c|c|c|c|c|c|c|c|}
\hline \multirow{2}{*}{$\begin{array}{l}\text { Sample } \\
\text { number }\end{array}$} & \multirow{2}{*}{ Layer } & \multicolumn{9}{|c|}{ Organic components, $\%$} & \multicolumn{7}{|c|}{ Inorganic components, $\%$} & \multicolumn{3}{|c|}{ Ratio } \\
\hline & & $\mathrm{CH}_{4}$ & $\mathrm{C}_{2} \mathrm{H}_{6}$ & $\mathrm{C}_{3} \mathrm{H}_{8}$ & $\mathrm{C}_{2} \mathrm{H}_{4}$ & $\mathrm{C}_{4} \mathrm{H}_{6}$ & $\mathrm{C}_{2} \mathrm{H}_{2}$ & $\mathrm{C}_{3} \mathrm{H}_{6}$ & $\mathrm{C}_{6} \mathrm{H}_{6}$ & $\begin{array}{c}\text { Organic } \\
\text { total }\end{array}$ & $\mathrm{H}_{2} \mathrm{~S}$ & $\mathrm{CO}_{2}$ & $\mathrm{H}_{2} \mathrm{O}$ & $\mathrm{H}_{2}$ & $\mathrm{CO}$ & $\mathrm{SO}_{2}$ & $\begin{array}{c}\text { Inorganic } \\
\text { total }\end{array}$ & A & B & $\mathrm{C}$ \\
\hline 1 & $\mathrm{~K}$ & 18 & & & & & 3.8 & & 5.9 & 27.7 & 19.7 & 24.6 & & & 28 & & 72.3 & 0.42 & 0.65 & 0.65 \\
\hline 3 & $\mathrm{~J}$ & 7.1 & & 3.1 & & & & 3.9 & & 14.1 & & 23.4 & & & 58.8 & 3.7 & 85.9 & 0.23 & 0.72 & 0.5 \\
\hline 5 & $\mathrm{~J}$ & 19.5 & & 12 & & & & 22.8 & & 54.3 & 27.5 & & & 18.2 & & & 45.7 & 1 & 0.58 & 0.36 \\
\hline 4 & $\mathrm{~J}$ & & 6 & & & & & & & 6 & 17 & & 30.1 & & 46.9 & & 94 & 0 & 1 & 0 \\
\hline 6 & $\mathrm{~T}$ & & & & 6.6 & & 5.6 & & & 12.2 & & 74.7 & & & & 13.1 & 87.8 & 0 & 0 & 0 \\
\hline 11 & $\mathrm{~T}$ & 11.5 & 3.5 & & & & & & & 15 & 12.9 & 72.1 & & & & & 85 & 0.14 & 1 & 0.77 \\
\hline 7 & $\mathrm{~T}$ & & 2.9 & & & & 5.2 & & & 8.1 & 13.8 & 27.1 & & 7.2 & 43.8 & & 91.9 & 0 & 0.36 & 0 \\
\hline 26 & $\mathrm{~T}$ & 8.8 & & & & & & 11.3 & & 20.1 & & 46.4 & & & & 33.5 & 79.9 & 0.16 & 0.44 & 0.44 \\
\hline 27 & $\mathrm{~T}$ & & & 17.2 & & & & & & 17.2 & 19.8 & 63 & & & & & 82.8 & 0 & 1 & 0 \\
\hline 9 & $\mathrm{~T}$ & 15.4 & & & & & 11 & & 6.5 & 32.9 & 15.1 & 52 & & & & & 67.1 & 0.23 & 0.47 & 0.47 \\
\hline 12 & $\mathrm{D}$ & 6.8 & & & & & 24.6 & & 12.6 & 44 & 17.6 & 38.4 & & & & & 56 & 0.15 & 0.15 & 0.15 \\
\hline 28 & $\mathrm{D}$ & 11.6 & & & 22 & & 11.6 & 21.8 & & 67 & 22 & & & 11 & & & 33 & 1 & 0.17 & 0.17 \\
\hline 13 & $\mathrm{D}$ & & 3.6 & & & & 9.2 & & & 12.8 & & 53.3 & & & & 33.9 & 87.2 & 0 & 0.28 & 0 \\
\hline 20 & $\mathrm{O}$ & 17.1 & & 6.1 & & 5.8 & & & & 29 & 19.8 & 38.3 & & 12.9 & & & 71 & 0.31 & 0.8 & 0.59 \\
\hline 22 & $\in$ & 5 & & & & & 1.8 & & 1.9 & 8.7 & & 91.3 & & & & & 91.3 & 0.05 & 0.57 & 0.57 \\
\hline 24 & $\in$ & & & 3.8 & & & & & & 3.8 & 3.1 & 77.1 & & & 16 & & 96.2 & 0 & 1 & 0 \\
\hline
\end{tabular}

Notes: $\mathrm{A}=\mathrm{CH}_{4} /\left(\mathrm{CH}_{2}+\mathrm{CO}_{2}+\mathrm{H}_{2} \mathrm{O}\right) ; \mathrm{B}=\left(\mathrm{CH}_{4}+\mathrm{C}_{2} \mathrm{H}_{6}+\mathrm{C}_{3} \mathrm{H}_{8}\right) /$ total organic components; $\mathrm{C}=\mathrm{CH}_{4} /$ total organic components

The 28 samples of inclusions are distributed in different layers: Five samples in the Cambrian, six in the Ordovician, four in the Devonian, eight in the Triassic, three in the Jurassic, and two in the Cretaceous. There are three pure gaseous inclusions, in which two are in the Triassic, and one in the Devonian. There are twelve samples of pure liquid inclusions: three in the Cambrian, five in the Ordovician, one in the Devonian, two in the Triassic, zero in the Jurassic, and one in the Cretaceous. There are thirteen gas-liquid two-phase inclusions: two in the Cambrian, one in the Ordovician, two in the Devonian, four in the Triassic, three in the Jurassic, and one in the Cretaceous (Table 3 and Fig. 3). The previous studies indicated that the Cambrian, Devonian and Triassic are the main hydrocarbon source rocks, and from Cambrian to Cretaceous there are advantageous reservoir beds. Four sets of source-reservoir-seal associations were developed in the Cambrian, Devonian, Triassic-Jurassic and Cambrian-Lower Tertiary (Jiang et al, 2001).
From Fig. 3, we can see that the Cambrian and Ordovician capture liquid hydrocarbon inclusions, reflecting the expulsion of Cambrian hydrocarbon source rocks. Therefore, in the Ordovician and Cambrian we can search for reservoirs from Cambrian hydrocarbon source rocks. Although the Devonian and Triassic mainly contain two-phase inclusions, they also contain pure gaseous hydrocarbon inclusions and pure liquid hydrocarbon inclusions, reflecting the characteristics of multi-time hydrocarbon expulsion and accumulation. When hydrocarbon source rocks are of low maturity, they mainly expel liquid hydrocarbons. Mature hydrocarbon source rocks may expel liquid and gaseous hydrocarbon, and hydrocarbon source rocks with high maturity largely expel gaseous hydrocarbon. Therefore, we can search for gas reservoirs in the Cambrian, and oil and gas reservoirs from Devonian to Triassic. The Jurassic contains two-phase inclusions, reflecting expulsion of Triassic mature hydrocarbon source rocks, and we can search for reservoirs in the Triassic System. 
Table 3 Types and contents of inclusions of different layers in the Yunlong Depression

\begin{tabular}{|c|c|c|c|c|c|c|}
\hline Layer & Cambrian & Ordovician & Devonian & Triassic & Jurassic & Cretaceous \\
\hline Number of samples & 5 & 6 & 4 & 8 & 3 & 2 \\
\hline Proportion of pure gaseous inclusions & & & $25 \%$ & $25 \%$ & & \\
\hline Proportion of pure liquid inclusions & $60 \%$ & $83.8 \%$ & $25 \%$ & $25 \%$ & & $50 \%$ \\
\hline Proportion of gas-liquid inclusions & $40 \%$ & $16.7 \%$ & $50 \%$ & $50 \%$ & $100 \%$ & $50 \%$ \\
\hline
\end{tabular}

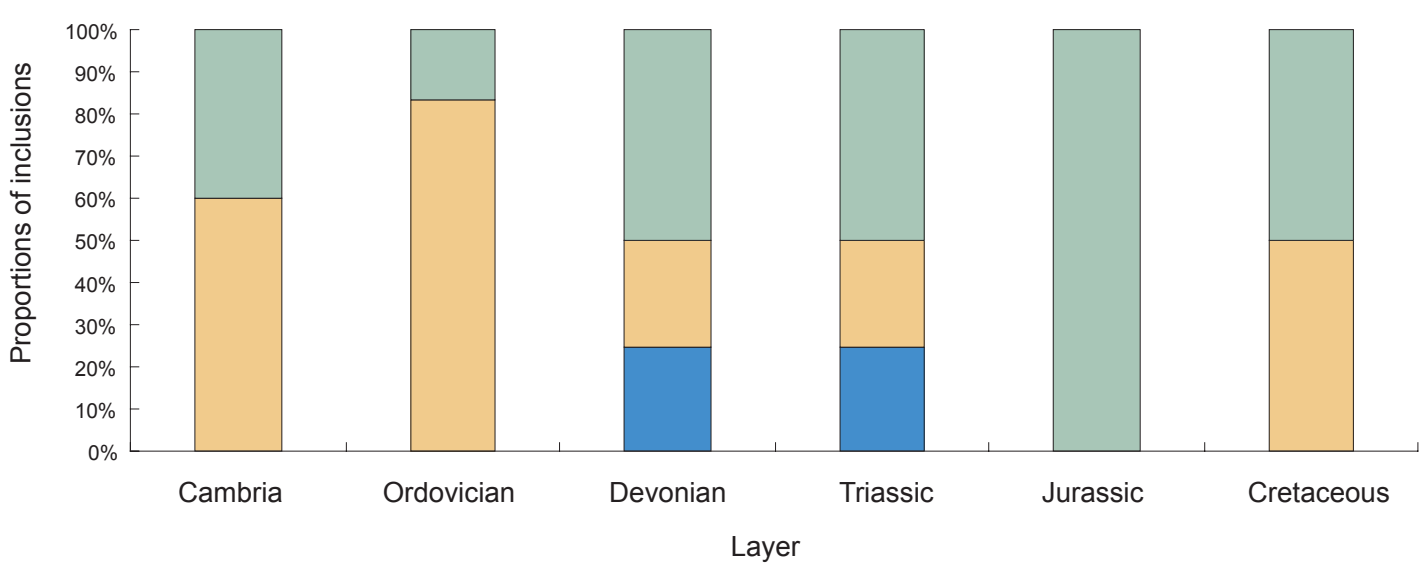

$\square$ Proportion of pure gaseous inclusions

$\square$ Proportion of pure liquid inclusions

$\square$ Proportion of gas-liquid inclusions

Fig. 3 Comparison of content of inclusions of different types in different layers

\section{Relationship between inclusion components and hydrocarbon reserves and accumulation}

\subsection{Devonian is the most productive formation}

The abundance of oil and gas in the reservoir can be indicated by the content of liquid hydrocarbons and gaseous hydrocarbons in organic inclusions. That is to say, the inclusion content can directly represent the abundance of oil and gas. If oil and gas were dominant when the mineral was crystallizing, the inclusion content was high. Therefore the relative amount of organic inclusions can be used to estimate the content of oil and gas in the reservoir (Zhang and Chen, 1993). The Devonian System is the most productive formation in both liquid and gas phases. The next is the Jurassic, Ordovician, Cretaceous and Triassic (Fig. 4 and Fig. 5). Prior research with conventional methods also concluded that the Devonian hydrocarbon source rock and reservoir bed are the best (Jiang et al, 2001). Some scholars insist that high mass fraction of organic components in inclusions means that the inclusions were captured during the peak stage of hydrocarbon accumulation. On the contrary, the inclusions were captured in the initial or late stage (Xu and Zou, 2001).

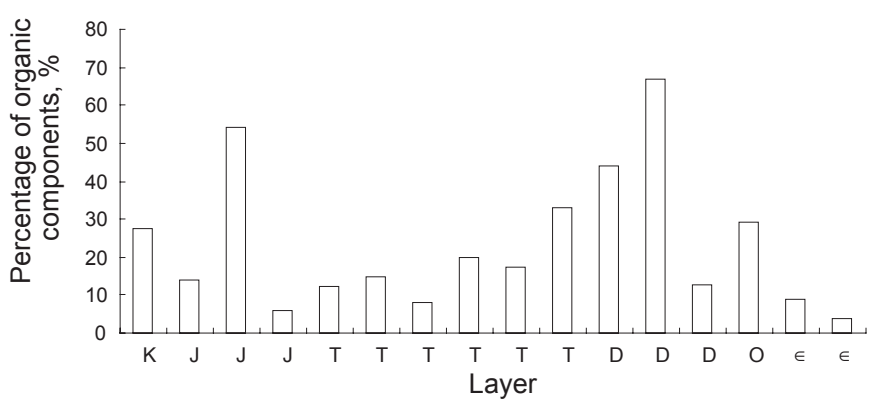

Fig. 4 Organic content of the gas phase in inclusions of different layers

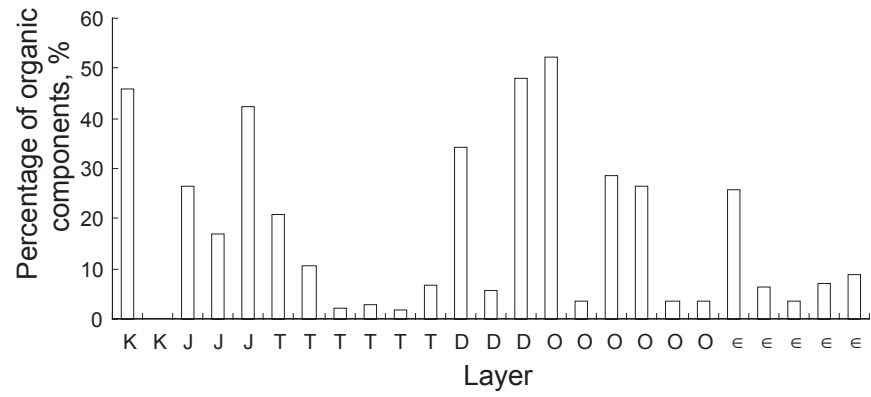

Fig. 5 Organic content of the liquid phase in inclusions of different layers 


\subsection{Multi-time accumulation in the study area}

The components of inclusions in different evolution stages represent the original components of the environment during the formation of inclusions. In practice, while crude oil evolved from a low maturity stage to final methane stage, the organic and inorganic compositions changed and the gaseous compositions also changed regularly. Some scholars consider that during the low maturity stage, $\mathrm{H}_{2} \mathrm{O}$ and $\mathrm{CO}_{2}$ are dominant, and during the stage of methane, $\mathrm{CH}_{4}$ is in the main component (Zhang and Chen, 1993). Some other scholars hold the opinion that, during the immature stage, $\mathrm{CH}_{4}$ is rich in the gas phase; during the mature stage, $\mathrm{C}_{2}-\mathrm{C}_{4}$ are rich, and during the over mature stage, $\mathrm{CH}_{4}$ again becomes the main component (Jiang et al, 2001).

From the content of methane, we can know that it is different in different formations. In the liquid phase, Devonian system, Cambrian system and Ordovician system have a high ratio of methane, and the next is Jurassic system, Cretaceous system and Triassic system. However, in the gas phase, the Jurassic system, Cretaceous system and Ordovician system have a higher content of methane (Fig. 6 and Fig. 7). This indicates that the evolution stages of hydrocarbon are different in different formations. In the same formation, different samples have different contents of methane. For example, in the liquid phase of the Ordovician system there are six samples, among which methane content of two samples is more than $15 \%$, one is less than $5 \%$, and methane does not exist in the other three samples. It demonstrates that this formation captured the hydrocarbons formed in different evolution stages or from different source rocks. From the distribution of methane content, there are four intervals, namely, $>15 \%, 15 \%-5 \%,<5 \%$, and 0 . It can be concluded that four stages of hydrocarbon accumulation or multi-stage expulsion occurred or oil and gas are in different evolution stages in this study area.

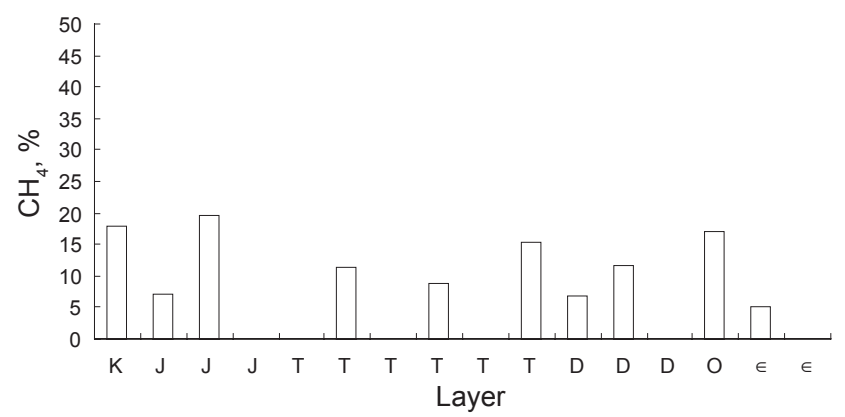

Fig. 6 Methane content of the gas phase in inclusions of different layers

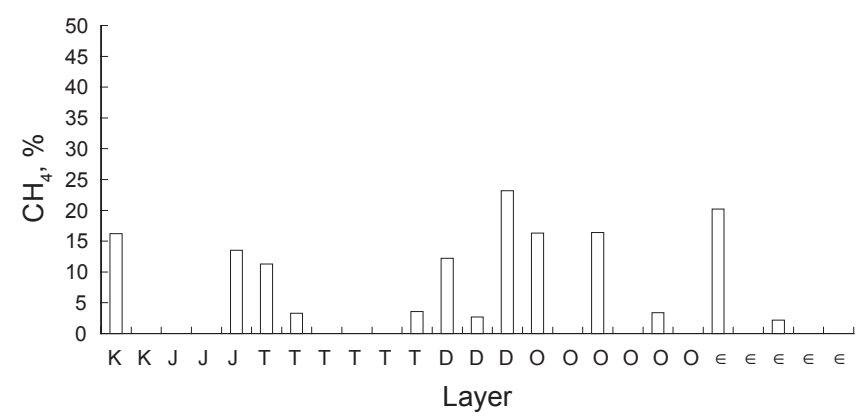

Fig. 7 Methane content of the liquid phase in inclusions of different layers
Besides the analysis of different components, an inductive method was used in this test. The content of organic components and inorganic components in the gas phase and liquid phase, the basic concentration of methane (the ratio of $\mathrm{CH}_{4}$ and $\mathrm{CH}_{2}+\mathrm{CO}_{2}+\mathrm{H}_{2} \mathrm{O}$, which is expressed by " $\mathrm{A}$ "), the ratio of paraffin hydrocarbon $\left(\mathrm{CH}_{4}+\mathrm{C}_{2} \mathrm{H}_{6}+\mathrm{C}_{3} \mathrm{H}_{8}\right)$ and total organic components (expressed by "B"), and the ratio of methane and total organic components (expressed by "C") were calculated. A reflects the extent of maturity. The larger the value of $\mathrm{A}$ is, the higher the maturity is, and otherwise the maturity is lower. B reflects the extent of hydrocarbon evolution, if inclusions of different $B$ values develop in the same sample, it means that hydrocarbons came from different stages. The larger the $\mathrm{C}$ is, the more the nonpolar molecules are and the less the polar molecules are $(\mathrm{Xu}$ et al, 1996). During the migration and accumulation process, according to the organic chemical property of hydrocarbons, non-polar molecules migrate first, and molecules with high polarity migrate late (Hunt, 1986; Li, 1994). Thus it can be seen that the values of $\mathrm{A}, \mathrm{B}$ and $\mathrm{C}$ indicate the extent of maturity of organic matter from different aspects, and reveal the accumulation stages and evolution characteristics of hydrocarbons (Xu and Zou, 2001). The results are shown in Table 1 and Table 2. Various histograms (Fig. 8-Fig. 13) are made to explain it directly.

From Table 1, Table 2, Fig. 8 and Fig. 9, we can know that the value of $\mathrm{A}$ is always low, because of a higher content of $\mathrm{CO}_{2}$ and $\mathrm{H}_{2} \mathrm{O}$. As vitrinite reflectance Ro is measured, the source rocks entered the mature stage, and source rocks in the Cambrian system were over mature. Perhaps as the generated hydrocarbon is limited, the value of $\mathrm{A}$ is low; or the oil

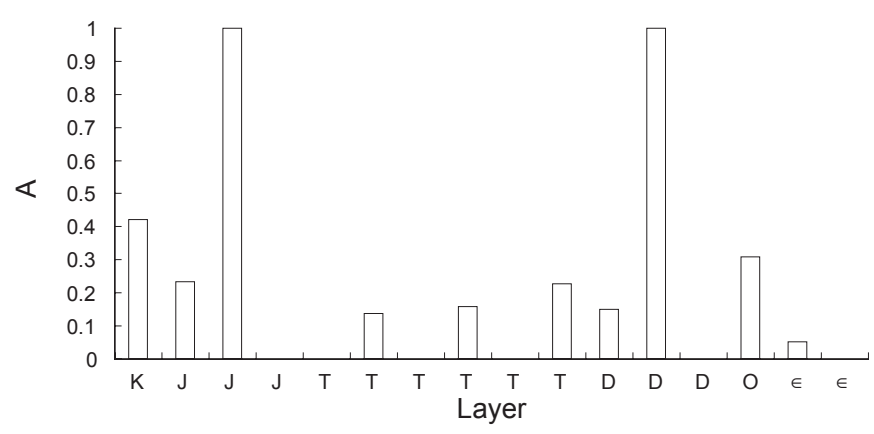

Fig. 8 Basic concentration of methane in the gas phase of inclusions $\left(\mathrm{A}=\mathrm{CH}_{4} /\left(\mathrm{CH}_{4}+\mathrm{CO}_{2}+\mathrm{H}_{2} \mathrm{O}\right)\right)$

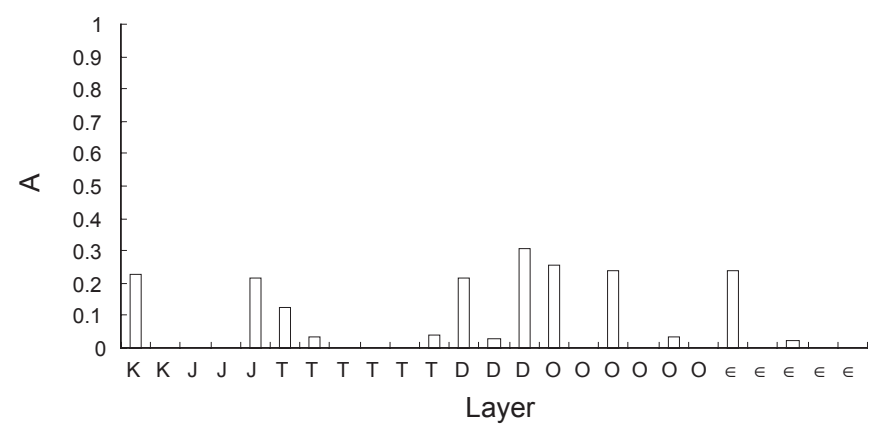

Fig. 9 Basic concentration of methane in the liquid phase of inclusions $\left(\mathrm{A}=\mathrm{CH}_{4} /\left(\mathrm{CH}_{4}+\mathrm{CO}_{2}+\mathrm{H}_{2} \mathrm{O}\right)\right)$ 
generated in the high maturity stage can not transfer into the reservoir because of worse preservation condition; or because we did not get the samples which have a high value of A.

However, we think that the first reason is the most possible. Although the value of A is low, three intervals still exist: $>0.2,0.2-0.1,<0.1$, which represent the high maturity, mature, and immature stages. When some scholars studied the components of fluid inclusions in the Dagang exploration area, they thought that the oil migrated during the high maturity stage, and the value of A could reach 0.55 at least (Xu and Zou, 2001). The Devonian system and Jurassic system have higher values of $A$, which reflect that oil was captured during the high maturity stage. From the values in the same formation, we can know that $\mathrm{A}$ is different in different formations, which means that oil came from stages of different maturities or different source rocks, and this study area has the characteristics of multi-time accumulation.

From Table 1, Table 2, Fig. 10 and Fig. 11, we can know that four intervals exist: $1-0.8,0.8-0.5,0.5-0.3,<0.3$, which means that the extent of evolution is becoming lower. The hydrocarbons which were captured in the Cambrian system, Ordovician system, Triassic system and Jurassic system, have the feature of high evolution in the high maturity stage.

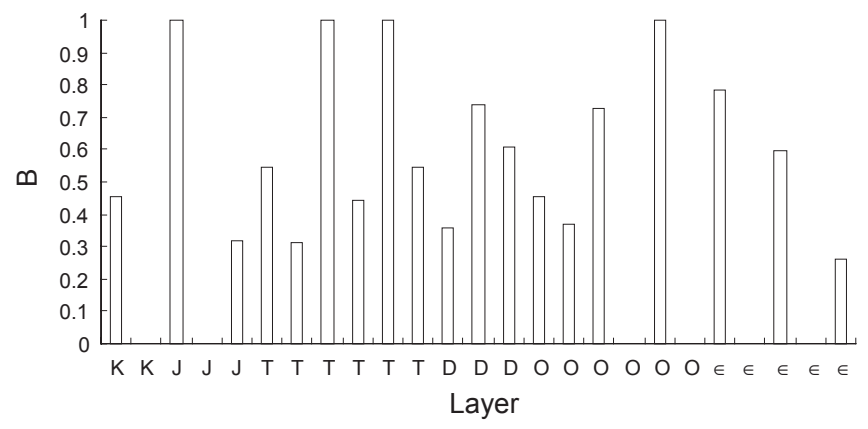

Fig. $10 \mathrm{~B}$ of liquid phase in inclusions ( $\mathrm{B}=\left(\mathrm{CH}_{4}+\mathrm{C}_{2} \mathrm{H}_{6}+\mathrm{C}_{3} \mathrm{H}_{8}\right) /$ total organic components $)$

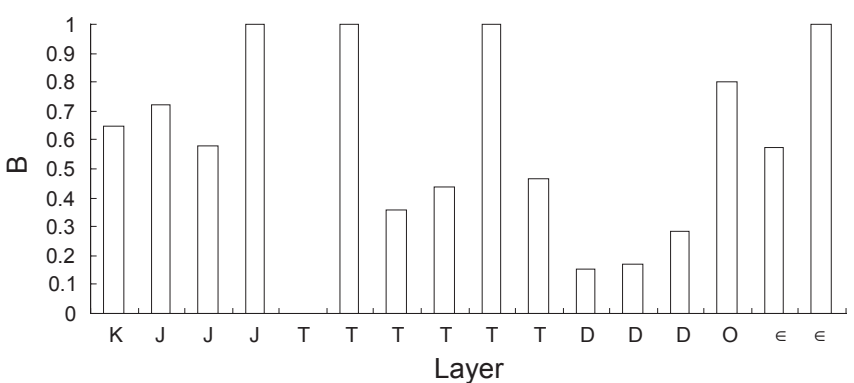

Fig. $11 \mathrm{~B}$ of gas phase in inclusions ( $\mathrm{B}=\left(\mathrm{CH}_{4}+\mathrm{C}_{2} \mathrm{H}_{6}+\mathrm{C}_{3} \mathrm{H}_{8}\right) /$ total organic components $)$

From Table 1, Table 2, Fig. 12 and Fig. 13, it can be seen that ratio $\mathrm{C}$ can also be divided into four intervals: $>0.7,0.7-0.35,<0.35$, and 0 , which are corresponding to the capture order in the over mature stage, mature stage, early mature stage and immature stage. On one hand, the hydrocarbon source rocks are different; on the other hand, it shows the accumulation order and multi-time migration of hydrocarbons.

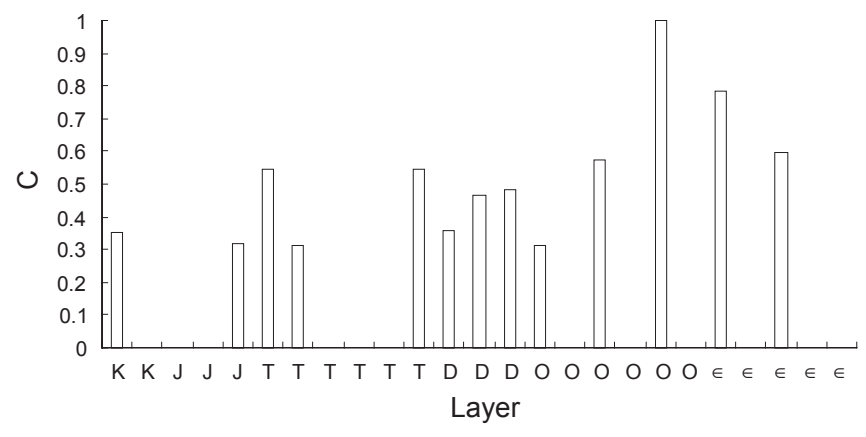

Fig. $12 \mathrm{C}$ of liquid phase in inclusions $\left(\mathrm{C}=\mathrm{CH}_{4} /\right.$ total organic components $)$

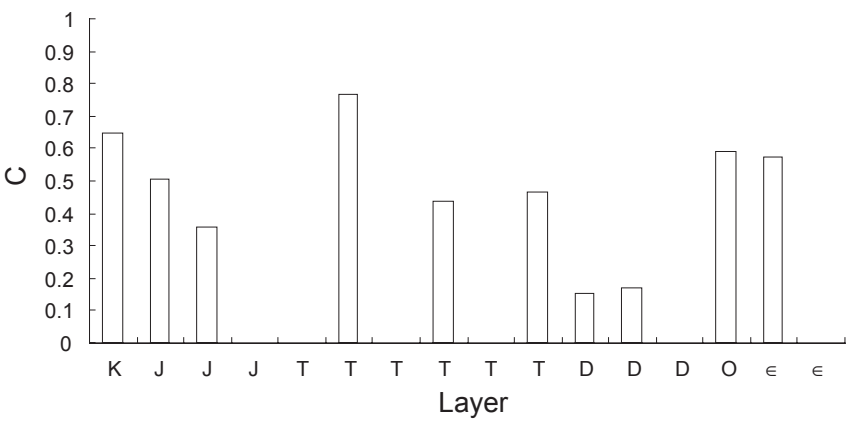

Fig. $13 \mathrm{C}$ of gas phase in inclusions $\left(\mathrm{C}=\mathrm{CH}_{4} /\right.$ total organic components $)$

\section{Conclusions}

1) Laser Raman probe analysis has become one of the most important methods for studying gas phase and liquid phase components of inclusions. There is a close relationship between components of organic inclusions and hydrocarbon accumulation.

2) The Cambrian and Ordovician capture liquid hydrocarbon inclusions, reflecting the possibility of oil pools. The Devonian, Triassic and Jurassic mainly contain twophase inclusions, reflecting the possibility of oil and gas pools.

3) The organic inclusion content is the richest in the Devonian, the next is in the Jurassic, Ordovician, Cretaceous and Triassic, and the lowest is in the Cambrian. Consequently, it can be inferred that oil and gas is the richest in the Devonian. This also supports the prior research findings with conventional methods.

4) From the content of methane in inclusions, we can know that the evolution stages of hydrocarbon were different in different formations and four stages of hydrocarbon accumulation could be defined in the study area.

\section{References}

Braithwaite C J R. Cement sequence stratigraphy in carbonates. Journal of Sedimentary Research. 1993. 63(2): 295-303

Feng Q, Ma S P and Fan A P. Characteristics of fluid inclusions in Upper Paleozoic reservoirs in Ordos basin and their geological significance. Oil \& Gas Geology. 2006. 27(1): 27-32 (in Chinese)

$\mathrm{He} \mathrm{Z} \mathrm{L}$ and Du J F. Some advances and trends in fluid inclusion research. Earth Science Frontiers. 1996. 3(4): 306-312 (in Chinese)

Hunt J M. Petroleum Geochemistry and Geology. Beijing: Petroleum 
Industry Press. 1986. 65-129 (in Chinese)

Itansen J R and Madsen J K. Advances and trend in fluid inclusion research in Denmark. Apifis Newsletter. 1995. 15(8): 1156-1160

Jiang L, Wang Y B, Wu P K, et al. Origin and composition of organic inclusions in Taibei Depression, East China Sea Basin. Chinese Journal of Geology. 2001. 36(2): 222-228 (in Chinese)

Levine J R, Samson I M and Hesse R. Occurrence of fracture-hosted impsonite and petroleum fluid inclusions, Quebec City region, Canada. AAPG Bulletin. 1991. 75(1): 139-155

Li M C. Oil and gas migration (Second Edition). Beijing: Petroleum Industry Press. 1994. 1-129 (in Chinese)

Liu C Y, Zhou Y Q, Du Y M, et al. Application of fluid inclusions in the study on hydrocarbon migration and accumulation and some problems worthy to be discussed. Journal of Xi'an Petroleum University. 2007. 22(1): 29-32 (in Chinese)

Mai B X and Wang B S. Characteristics and applications of fluid inclusions in the Eogene System of the Biyang Depression. Chinese Journal of Geochemistry. 1991. 11(4): 331-341 (in Chinese)

Mei L F, Xu S H, Ni C X, et al. Fracturing and hydrocarbon migration in Wangchang area, Jianghan Basin. Chinese Science Bulletin. 1994. 39(14): 1312-1315 (in Chinese)

Pan L Y, Ni P, Ou G X, et al. Multistage petroleum charges in the Silurian of Tazhong north slope of the Tarim Basin, northwest China: evidence from fluid inclusions and organic geochemistry. Acta Petrologica Sinica. 2007. 23(1): 131-136 (in Chinese)

Sasada M. Trends in fluid inclusion researches in Japan. Apifis Newsletter. 1995. 15(8): 1188-1194

Shelton K L, Bauer R M and Gregg J M. Fluid-inclusion studies of regionally extensive epigenetic dolomites, Bonneterre Dolomite (Cambrian), southeast Missouri: evidence of multiple fluids during dolomitization and lead-zinc mineralization. Geological Society of America Bulletin. 1992. 104(6): 673-683

Shi J X and Li B C. Study on application of organic inclusions as a discriminant indicator for gas migration. Oil and Gas Geology. 1991. 12(2): 185-194 (in Chinese)

Tan J X, Zhang C J, Li T S, et al. Fluid inclusion in Xichang Basin and its application to hydrocarbon exploration. Oil and Gas Geology. 1994. 15(3): 216-225 (in Chinese)

Wang F, Zeng Q H, Liu D H, et al. Petroleum inclusions in diabase: implications to the formation of oil and gas pools in Linyi Sag. Geochimica. 2006. 35(3): 285-294 (in Chinese)

Xu P C, Li R B, Wang Y Q, et al. Raman spectroscopy in earth sciences. Xi'an: Shanxi Science \& Technology Press. 1996. 1-176 (in Chinese)

$\mathrm{Xu}$ X C and Zou H F. The features of the compositions of fluid inclusions in Dagang oil field and its applications. Journal of Changchun University of Science and Technology. 2001. 31(3): 251-256 (in Chinese)

Zhang W H and Chen Z Y. The geology of fluid inclusions. Wuhan: China University of Geosciences Press. 1993. 190-191 (in Chinese)

Zhang Z J and Zhang W H. Study on the mechanism of organic inclusion in the fragmental reservoir. Geological Science and Technology Information. 1994. 13(1): 33-58 (in Chinese)

Zheng Y Y, Wang S Y, Li X J, et al. Application of organic inclusion research in petroleum geology. Geology-Geochemistry. 1998. 26(2): 72-76 (in Chinese)

Zhu Z Q and Zeng J H. Feature of fluid inclusions and the period of petroleum accumulation in Linnan Sag. Journal of Southwest Petroleum University. 2008. 30(4): 31-34 (in Chinese)

(Edited by Hao Jie) 